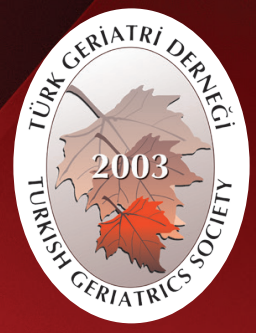

Turkish Journal of Geriatrics

DOI: 10.31086/tigeri.2018240421

2018:21 (2):206-214

- Ferdane Özlem AKARSU²

- Ferdi KÖŞGER ${ }^{1}$

- Altan EŞSizOĞLU'

- Belgin Demet

ÖZBABALIK ADAPINAR ${ }^{3}$

\title{
THEORY OF MIND IN AMNESTIC MILD COGNITIVE IMPAIRMENT AND ITS RELATIONSHIP WITH LANGUAGE AND MEMORY FUNCTIONS
}

\section{Abstract}

Introduction: Although it has been proven that theory of mind functions is deteriorated in amnestic type mild cognitive impairment, the relationship between this deterioration and cognitive functions has not been researched. The aim of this study is to compare amnestic type mild cognitive impairment patients with healthy individuals in terms of theory of mind functions and to determine the relationship between theory of mind functions and the functions of language and memory in amnestic type mild cognitive impairment patients.

Materials and Method: Thirty-eight patients with amnestic type mild cognitive impairment were compared with 34 healthy individuals in this study. The Reading the Mind in the Eyes Test, Hinting Test, Boston Naming Test, Wechsler Adult Intelligence Scale-Revised Vocabulary Test Score, Öktem Verbal Memory Process Test, and Clock Drawing Test were used for evaluation.

Results: The scores of the amnestic type mild cognitive impairment group in the tests evaluating theory of mind functions and the functions of language, memory and Clock Drawing Test were lower than those of the control group. The scores of the amnestic type mild cognitive impairment group in the tests evaluating the theory of mind functions were not associate with the tests evaluating the functions of language and memory.

Conclusion: Amnestic type mild cognitive impairment patients perform worse in terms of affective and cognitive theory of mind functions compared with healthy aging individuals. The impairment of theory of mind functions in amnestic type mild cognitive impairment patients is thought to be independent of the deterioration of language and memory functions.

Keywords: Cognitive dysfunction; Theory of mind; Memory; Language

ARAŞTIRMA

CORRESPONDANCE

Altan EŞSiZOĞLU

Eskişehir Osmangazi University, Faculty of Medicine, Department of Psychiatry, Eskişehir, Turkey

Phone: 2222392979

Fax: 2222392979

e-mail: altanessizoglu@gmail.com

Received: 12/12/2017

Accepted: 30 03/2018

Eskişehir Osmangazi University, Faculty of

Medicine, Department of Psychiatry,

Eskişehir, Turkey

Eskişehir Osmangazi University, Faculty of

Medicine, Department of Neurology,

Eskişehir, Turkey

${ }^{3}$ Eskişehir Acıbadem Hospital, Neurology

Clinic, Eskişehir, Turkey

\section{AMNESTIK TIP HAFIF KOGNITIF BOZUKLUKTA ZIHIN KURAMI VE DIL VE BELLEK İ̧̧LEVLERi íLE İLişKisi}

$\ddot{O}_{z}$

Giriş: Amnestic tip hafif kognitif bozuklukta, zihin kuramı işlevlerinin bozulduğu ortaya konmasına karşın bu bozulmanın bilişsel işlevlerle olan ilişkisi araştııımamıştı. Bu çalışmanın amacı amnestic tip hafif kognitif bozuklukta bulunan hastalar ile sağlıklı kişileri zihin kuramı işlevleri bakımından karşılaştırmak ve amnestic tip hafif kognitif bozuklukta zihin kuramı işlevlerinin dil ve bellek işlevleri ilişkisini belirlemektir.

Gereç ve Yöntem: Bu çalışmada 38 amnestic tip hafif kognitif bozukluk hastası ile 34 sağlıklı katılımcı karşılaştııılmıştır. Değerlendirme amacıyla Gözlerden Zihin Okuma Testi, İmayı Anlama Testi, Boston Adlandırma Testi, Wechsler Yetişkinler İçin Zeka Ölçeği Revize Formu Sözcük Dağarcığı Alt Testi, Öktem Sözel Bellek Süreçleri Testi, Saat Çizme Testi kullanılmıştır.

Bulgular: Bu çalışmada amnestic tip hafif kognitif bozukluk grubu kontrol grubuna göre zihin kuramı işlevlerini değerlendiren testler ile dil ve bellek işlevlerini değerlendiren testlerden ve Saat Çizme Testi'nden kontrol grubuna göre daha düşük puan almıştır. Amnestic tip hafif kognitif bozukluk grubunun zihin kuramı işelevlerini değerlendiren testlerden aldığı puanların dil ve bellek işlevlerini değerlendiren testler ile ilişkili olmadığı saptanmıștır.

Sonuç: Amnestic tip hafif kognitif bozuklukta hastaları ile sağlıklı yaşlanan kişiler arasında affektif ve kognitif zihin kuramı işlevi açısından daha kötü performans göstermektedir. Amnestic tip hafif kognitif bozuklukta hastalarındaki zihin kuramı işlevlerindeki bozulmanın dil ve bellek işlevlerindeki bozulmadan bağımsız olduğu düşünülmüştür.

Anahtar sözcükler: Kognitif bozukluk; Zihin kuramı; Bellek; Dil 


\section{INTRODUCTION}

Mild cognitive impairment (MCl) accompanied by complaints about memory is called amnestic type $\mathrm{MCl}(\mathrm{aMCl})$. The diagnostic criteria for a $\mathrm{MCl}$ are complaints about memory confirmed by a patient's relative, an ordinary course of general cognitive functions and daily life activities, the existence of a memory disorder determined by age and education norms, and the absence of dementia (1).

The concept of theory of mind (ToM) is defined as an individual's ability to realize that others have different mind from his/her own and to understand and represent his/her own and others' mental status as intentions, belief, desires, and level of knowledge. Two types of ToM have been defined as cognitive ToM and affective ToM (2).

The importance of evaluating the functions of ToM to make predictions about the possibility of $\mathrm{MCl}$ transforming into Alzheimer's disease (AD) has motivated researchers to conduct studies, which have identified that patients with aMCl perform worse in terms of ToM functions (3). The relationship between cognitive and ToM functions in patients with $\mathrm{aMCl}$ has not been studied.

The purpose of this study is to compare aMCl patients with healthy individuals in terms of ToM functions and to determine the relationship between ToM functions and the functions of language and memory in aMCl patients.

\section{MATERIALS AND METHOD}

\section{Sample}

The study sample was composed of patients admitted to the neurology polyclinic between October 2012 and June 2014 with complaints of dysmnesia. Those who were diagnosed with $\mathrm{aMCl}$, and accepted to participate in the study were assigned to the patient group, while those who were not diagnosed with $\mathrm{aMCl}$ but were willing to take part in the study were assigned to the control group. The inclusion criteria for both groups were age 50 years or older, literate, scoring 24 or over on the Standardized Mini-Mental State Examination, scoring 0.5 or lower on the Clinical Dementia Rating Scale, and scoring 3 or lower on the Hachinski Ischaemic Scale. Meeting the Petersen Criteria was an additional criterion for inclusion in the aMCl group. Taking a type of medication affecting cognitive function, having a history of head trauma, scoring 14 or over on the Geriatric Depression Scale, having focal brain injury, and alcohol and drug abuse were the exclusion criteria. Seven patients were excluded due to the changes observed in brain MR imaging, four patients were excluded due to alcohol use, and three patients were excluded due to nonacquiescence to participate in the study. Therefore, data collection methods were applied to 38 patients diagnosed with $\mathrm{aMCl}$ and 34 individuals in the control group.

\section{Data collection methods}

Sociodemographic characteristics and clinical features information form: The features of age, gender, marital status, education status, income level, employment and economic status, and information related to the patient's and his/her relatives' accounts about amnesia, dementia family history, head trauma, general anesthesia intake after 50 years of age, smoking, and alcohol and substance use were collected through this form.

Clinical Dementia Rating (CDR) Scale: This scale was developed to evaluate the functional destruction in $A D(4)$; it is used to measure a patient's cognitive and functional performance. The purpose of using this scale in the study is to identify whether the participant meets the necessary criteria for participation in the study.

Standardized Mini-Mental State Examination (SMMSE): This is a commonly used cognitive survey tool (5), and the validity and reliability of its Turkish version have been completed (6).

The Reading the Mind in the Eyes Test (Eyes Test): Eyes Test was developed to evaluate affect 
recognition (7). The validity and reliability of the Turkish version have been assessed $\left(\mathrm{KR}_{20}\right.$ was 0.72) (8). During the administration of the test, the participant is instructed to check the choice that best suits his/her thoughts and feelings about the eyes in the image. A high score indicates good affective ToM function.

Hinting Test: One of the stories applied to secondtier ToM functions was used in this study (9). Through this story, the ability to uncover the real intention behind implicitly stated expressions is evaluated. The participant is told a story, wherein Elif, whose birthday is coming, tells her father that she loves animals, especially dogs. Then, the participant is asked what Elif's real intention is and scores two points if he/she gives the correct answer. If the participant cannot give the correct answer, then the story is continued by recounting another of Elif's statements, wherein she asks her father whether pet shops are open on her birthday. Then, the participant is asked what Elif wants her father to do. The correct answer scores one point at this stage. If there is no correct answer, the participant does not score any points. This story has been used in previous studies in Turkey. In this study, a similar methodology has been used in terms of statistics (10).

Boston Naming Test (BNT): This test is used to evaluate naming ability skill (11). The shortened version containing 31 images was used in this study. The Turkish adaptation and norm determination study of the test is completed but not has been published yet.

Wechsler Adult Intelligence Scale-Revised Vocabulary Subtest (WAIS-R): Developed by Wechsler (12), this vocabulary subtest (WAIS-R/VTS) is used to measure the abilities of vocabulary use and self-expression, sensitivity to new information, storage in the long-term memory, and re-grouping when necessary. The Turkish standardization study of the test has been completed (13).

Öktem Verbal Memory Process Test (ÖktemVMPT): This test has been developed to research verbal learning and memory in terms of multiple factors. The Öktem-VMPT has been standardized, and normal scores have been identified for the variables age, gender, and education (14). The Immediate memory, Learning, Achieving Criteria, Spontaneous Recall, and Recognition subtests were used in this study. This test was also used to identify the criteria for determination of memory impairment (the case in which the score for episodic memory is lower than normal values as 1.5 standard deviation) when adapted to the Petersen Criteria.

Clock Drawing Test (CDT): This test is a part of the Boston Diagnostic Aphasia Examination (15), and the validity and reliability of the Turkish version have been assessed (16). The cognitive features measured by the test are comprehension, planning, visual memory and reconstruction, visual-spatial ability, motor planning and method, digital information, abstract thinking, inhibiting the tendency created by the physical features of the stimulant, concentration, and tolerance against detention.

Geriatric Depression Scale (GDS): Based on self-report assessment, this scale is used to identify depression in the elderly (17). The validity and reliability of the Turkish version have been assessed (18).

Functional Activities Questionnaire (FAQ): Based on self-report assessment, this questionnaire evaluates 10 mixed daily activities (19). A Turkish adaptation study of the FAQ suitable for the 50 years and older age group has been completed (20).

\section{Statistical analysis}

The data obtained were analyzed in Statistical Package for Social Sciences 21.0 version. The Kolmogorov-Smirnov test was applied in order to show the normal distribution (95\% confidence interval). The groups were compared in terms of normally distributed, continuous numerical variables by t-test, non-normally distributed variables by 
Mann-Whitney $U$ test, and categorical variables by Pearson's Chi-Square test. For the purpose of identifying the variables predicting the scores of the aMCl group on the Eyes Test and Hinting Test, linear regression analysis was applied to the variables that were determined to have statistical significance.

\section{RESULTS}

The proportion of participants who graduated from primary school in the aMCl group was significantly higher than that in the control group, whereas the duration of education and monthly income of the aMCl group were found to be significantly lower $\left(X^{2}=8.943\right.$ and $p=0.011 ; z=-2.36$ and $p=0.018$; $z=-2.09$ and $p=0.036$, respectively) (Table 1 ).
The FAO scores of the $\mathrm{aMCl}$ group were significantly higher than those of the control group $(\mathrm{z}=-2.921$ and $\mathrm{p}<0.01)$. The $\mathrm{aMCl}$ group scored significantly lower than the control group on the Eyes Test; SMMSE; Immediate Memory, Learning Score, Spontaneous Recall, Recognition, BNT, WAIS-R/VST; CDT; and Hinting Test $(t=-5.013$ and $p<0.001 ; z=-5.681$ and $p<0.001 ; z=-4.487$ and $p<0.001 ; z=-6.009$ and $p<0.001 ; z=-6.925$ and $p<0.001 ; \quad z=-3.346$ and $p<0.01 ; z=-3.543$ and $p<0.001 ; z=-5.249$ and $p<0.001 ; z=-3.710$ and $p<0.001 ; z=-3.386$ and $p<0.01$, respectively) (Table 3).

According to the result of linear regression analysis, the score of the aMCl group on the Eyes Test and Hinting Test were not predicted by the independent variables (Table 4 and 5).

Table 1. Comparison of the aMCl and control groups in terms of sociodemographic data.

\begin{tabular}{|c|c|c|c|c|}
\hline & $\mathrm{aMCl}(\mathrm{n}=38)$ & Control $(n=34)$ & & \\
\hline & mean \pm sd & mean $\pm s d$ & $t / z$ & $\mathbf{P}$ \\
\hline Age & $64.89 \pm 6.00$ & $62.38 \pm 5.03$ & 1.911 & 0.060 \\
\hline Duration of education (year)* & $8.92 \pm 4.21$ & $11.53 \pm 4.41$ & -2.36 & 0.018 \\
\hline \multirow[t]{2}{*}{ Monthly income* } & $2329.47 \pm 1751.11$ & $3295.88 \pm 2319.50$ & -2.09 & 0.036 \\
\hline & n (\%) & n (\%) & $x^{2}$ & $\mathbf{P}$ \\
\hline Gender & & & 1.583 & 0.208 \\
\hline Female & $19(46.3 \%)$ & $22(53.7 \%)$ & & \\
\hline Male & $19(61.3 \%)$ & $12(38.7 \%)$ & & \\
\hline Marital Status & & & 0.632 & 0.729 \\
\hline Single & $2(40.0 \%)$ & $3(60.0 \%)$ & & \\
\hline Married & $31(52.5 \%)$ & $28(47.5 \%)$ & & \\
\hline Widowed/divorced & $5(62.5 \%)$ & $3(37.5 \%)$ & & \\
\hline Education Level & & & 8.943 & 0.011 \\
\hline Primary school & $22(73.3 \%)$ & $8(26.7 \%)$ & & \\
\hline High school & $8(42.1 \%)$ & $11(57.9 \%)$ & & \\
\hline University & $8(34.8 \%)$ & $15(65.2 \%)$ & & \\
\hline Employment & & & 1.496 & 0.473 \\
\hline Housewife & 13 (61.9\%) & 8 (38.1\%) & & \\
\hline Employed & $3(37.5 \%)$ & $5(62.5 \%)$ & & \\
\hline Retired & 22 (51.2\%) & $21(48.8 \%)$ & & \\
\hline
\end{tabular}

* Mann-Whitney U test 
Table 2. The comparison of aMCl and control groups in terms of some characteristics.

\begin{tabular}{|c|c|c|c|c|}
\hline & $\mathrm{aMCl}(\mathrm{n}=38)$ & Control $(n=34)$ & & \\
\hline & n (\%) & n (\%) & $x^{2}$ & $\mathrm{p}$ \\
\hline Amnesia (relative) & & & 5.105 & 0.024 \\
\hline Yes & $20(69.0 \%)$ & $9(31.0 \%)$ & & \\
\hline No & 19 (61.3\%) & $12(38.7 \%)$ & & \\
\hline Amnesia (self-report) & & & 3.512 & 0.061 \\
\hline Yes & 31 (59.6\%) & $21(40.4 \%)$ & & \\
\hline No & 7 (35.0\%) & $13(65.0 \%)$ & & \\
\hline History of head trauma & & & 2.316 & 0.128 \\
\hline Yes & 1 (20.0\%) & 4 (80.0\%) & & \\
\hline No & $37(55.2 \%)$ & $30(44.8 \%)$ & & \\
\hline Family dementia history & & & 1.116 & 0.291 \\
\hline Yes & 12 (61.9\%) & 7 (38.1\%) & & \\
\hline No & $26(49.1 \%)$ & 27 (50.9\%) & & \\
\hline History of psychiatric treat. & & & 3.453 & 0.063 \\
\hline Yes & $8(80.0 \%)$ & $2(20.0 \%)$ & & \\
\hline No & $30(48.4 \%)$ & $32(51.6 \%)$ & & \\
\hline General anesthesia after 50 & & & 0.317 & 0.574 \\
\hline Yes & $10(47.6 \%)$ & $11(52.4 \%)$ & & \\
\hline No & 28 (54.9\%) & $23(45.1 \%)$ & & \\
\hline Smoking & & & 0.399 & 0.819 \\
\hline Yes & $6(54.5 \%)$ & $5(45.5 \%)$ & & \\
\hline No & $22(50.0 \%)$ & $22(50.0 \%)$ & & \\
\hline Gave up & $10(58.8 \%)$ & $7(41.2 \%)$ & & \\
\hline
\end{tabular}

Table 3. Comparison of the aMCl and control groups in terms of neurocognitive tests, ToM, and scales.

\begin{tabular}{|c|c|c|c|c|}
\hline & $\mathrm{aMCl}(\mathrm{n}=38)$ & Control $(n=34)$ & & \\
\hline & mean $\pm s d$ & mean $\pm s d$ & $t / z$ & $\mathrm{p}$ \\
\hline Eyes Test & $15.00 \pm 4.15$ & $19.82 \pm 3.98$ & -5.013 & $<0.001$ \\
\hline SMMSE* & $27.60 \pm 1.28$ & $29.47 \pm 0.74$ & -5.681 & $<0.001$ \\
\hline Immediate Memory* & $5.07 \pm 1.66$ & $7.38 \pm 2.01$ & -4.487 & $<0.001$ \\
\hline Learning* & $103.39 \pm 18.32$ & $130.82 \pm 11.57$ & -6.009 & $<0.001$ \\
\hline Achieving Criteria* & $4.00 \pm 4.23$ & $5.26 \pm 2.01$ & -1.182 & 0.237 \\
\hline Spontaneous Recalling* & $10.34 \pm 1.69$ & $14.11 \pm 1.00$ & -6.925 & $<0.001$ \\
\hline Recognition* & $13.55 \pm 1.75$ & $14.67 \pm 0.58$ & -3.346 & $<0.01$ \\
\hline BNT* & $28.00 \pm 2.73$ & $30.00 \pm 1.45$ & -3.543 & $<0.001$ \\
\hline WAIS-R (VTS) & $47.78 \pm 10.28$ & $60.41 \pm 6.37$ & -5.249 & $<0.001$ \\
\hline $\mathrm{CDT}^{\star}$ & $4.42 \pm 0.85$ & $4.97 \pm 0.17$ & -3.710 & $<0.001$ \\
\hline Hinting Test* & $1.52 \pm 0.55$ & $1.91 \pm 0.28$ & -3.386 & $<0.01$ \\
\hline GDS* & $11.50 \pm 6.18$ & $9.73 \pm 4.82$ & -1.175 & 0.240 \\
\hline FAQ* & $0.65 \pm 1.23$ & $0.06 \pm 0.34$ & -2.921 & $<0.01$ \\
\hline
\end{tabular}

* Mann-Whitney $U$ 
Table 4. Regression analysis results of the factors predicting the total score of the aMCl group on the Eyes Test.

\begin{tabular}{lrrrrr}
\hline Independent Variables & $\mathbf{B}$ & $\mathrm{SE}$ & Standardized $\boldsymbol{\beta}$ & $\mathbf{t}$ & $\mathbf{p}$ \\
\hline Constant & -2.428 & 22.251 & - & -0.109 & 0.914 \\
Education & -1.372 & 1.736 & -0.427 & -0.790 & 0.439 \\
Period of education & 0.308 & 0.517 & 0.311 & 0.596 & 0.558 \\
Monthly income & 0.001 & 0.001 & 0.367 & 1.124 & 0.275 \\
Amnesia (relative) & -2.110 & 1.773 & -0.282 & -1.190 & 0.249 \\
SMMSE & 0.445 & 0.761 & 0.138 & 0.585 & 0.565 \\
Immediate memory & 0.003 & 0.746 & 0.001 & 0.004 & 0.997 \\
Learning & 0.062 & 0.091 & 0.265 & 0.677 & 0.507 \\
Spontaneous recalling & 0.757 & 0.839 & 0.303 & 0.902 & 0.379 \\
Recognition & -0.832 & 0.766 & -0.319 & -1.087 & 0.291 \\
BNT & -0.273 & 0.553 & -0.178 & -0.493 & 0.628 \\
WAIS-R (VTS) & 0.210 & 0.169 & 0.512 & 1.245 & 0.228 \\
CDT & 0.056 & 1.275 & 0.11 & 0.44 & 0.965 \\
Hinting test & 2.155 & 1.658 & 0.288 & 1.304 & 0.208 \\
FAO & 0.144 & 1.023 & 0.034 & 0.112 & 0.912 \\
\hline
\end{tabular}

Table 5. Regression analysis results of the factors predicting the total score of the $\mathrm{aMCl}$ group in the Hinting Test.

\begin{tabular}{lrrrrr}
\hline Independent Variables & $\mathbf{B}$ & SE & Standardized $\boldsymbol{\beta}$ & $\mathbf{t}$ & $\mathbf{p}$ \\
\hline Constant & 4.800 & 2.747 & - & 1.748 & 0.097 \\
Education & -0.26 & 0.235 & -0.061 & -0.113 & 0.912 \\
Period of education & -0.018 & 0.069 & -0.134 & -0.256 & 0.800 \\
Monthly income & -1.915 & 0.000 & -0.061 & 0.181 & 0.858 \\
Amnesia (relative) & -0.034 & 0.244 & -0.034 & -0.139 & 0.891 \\
SMMSE & -0.109 & 0.099 & -0.254 & -1.105 & 0.283 \\
Immediate memory & -0.109 & 0.096 & -0.328 & -1.137 & 0.270 \\
Learning & 0.009 & 0.012 & 0.296 & 0.763 & 0.455 \\
Spontaneous recalling & -0.104 & 0.111 & -0.310 & -0.930 & 0.364 \\
Recognition & 0.002 & 0.105 & 0.005 & 0.016 & 0.987 \\
BNT & 0.015 & 0.074 & 0.075 & 0.208 & 0.837 \\
WAIS-R (VTS) & 0.009 & 0.023 & 0.168 & 0.396 & 0.696 \\
CDT & -0.034 & 0.169 & -0.051 & -0.200 & 0.843 \\
FAO & -0.185 & 0.129 & -0.413 & -1.429 & 0.169 \\
Eyes Test & 0.038 & 0.029 & 0.285 & 1.304 & 0.208 \\
\hline
\end{tabular}




\section{DISCUSSION}

The number of primary school graduates in the aMCl group was higher than those in the control group, whereas the mean of duration of education and the average monthly income of the aMCl group was lower than those of the control group. Although it is not exactly known to what extent a higher level of education affects $A D$, it has been indicated that a higher level of education may have an important function, because people with higher education more easily develop strategies to compensate for the possible adverse effects of cognitive impairment in the early stages of $A D$, and hence the effects of symptoms on daily life present late (21). The risk of developing AD decreases at a rate of $17 \%$ for each extra year of education, while having a lower economic level and a lower status occupation poses an increased risk of $A D$ development (22). Considering that a $\mathrm{MCl}$ poses a risk of $A D$ development, the results of this study suggest that duration of education and economic level also influence the risk of aMCl. Since there are few studies, there is a need for more studies to be performed on this aspect.

When the groups were compared in terms of complaints about amnesia, the relatives of the $\mathrm{aMCl}$ group reported more cases of amnesia complaints than those of the control group. Concurrently, the $\mathrm{aMCl}$ group scored lower than the control group on the Öktem-VMPT (Immediate Memory, Learning, Spontaneous Recalling, and Recognition), which was performed to evaluate verbal memory. Among the clinical diagnostic criteria for aMCl are the items of "memory problem expressed by the patient himself" and "identifying the memory problem adjusted for age" (1). The scores of the $\mathrm{aMCl}$ group on the $\mathrm{FAO}$ were higher than those of the control group. However, the average score of the $\mathrm{aMCl}$ group was within the normal limits when the normal scores for these age groups was considered. Therefore, the aMCl group met the "the daily life activities of the patient are normal with regard to his/her age" criterion, which is requisite for the diagnosis of $\mathrm{aMCl}$.

The language skills scores of the aMCl group in the BNT and WAIS-R/VST were lower than those of the control group. Impaired language skills in aMCl patients have also been proven by similar studies performed with the same tests as those used in this study (23). The aMCl group scored lower than the control group on the Hinting Test. While ToM functions are typically impaired with increasing age, several studies have indicated that particularly second-tier ToM functions are deteriorated in aMCl patients, posing a risk for $\mathrm{AD}$ development (24). For this reason, as the deterioration of ToM functions in aMCl patients could be observed in clinical presentation, it is important that this deterioration has the potential to identify patients who will develop AD. This result agrees with that of a similar study in which aMCl patients scored lower than healthy elderly in terms of first- and secondtier false-belief tasks. The performance of aMCl patients in the Eyes Test was also lower than that of the control group, although the difference was not significant. The aMCl group was also compared with healthy controls in terms of ToM functions by using brain imaging methods, and it was concluded that activation of the superior temporal sulcus (STS) in the right hemisphere, which is related to affective ToM, is lower in aMCl patients than in healthy controls. Researchers have indicated that the decrease in STS activation in aMCl patients is an early neural finding of the deterioration of affective ToM functions that will develop in the future (24). According to the results of this study, the Eyes Test performance of aMCl patients was significantly lower than that of healthy controls, which disagrees with the aforementioned study. The possible reason for this difference may be that this study was performed on a larger sample. 
It was indicated in this study that language and memory functions expected to deteriorate in $\mathrm{aMCl}$ patients did not predict the impaired cognitive and affective ToM functions, contrary to the case in healthy controls. It has been reported that ToM and cognitive functions are independent of each other (10). Our study supports this result, and we conclude that cognitive and affective ToM functions also become impaired independently of language and memory functions in a $\mathrm{MCl}$ patients.

The limitations of this study are that it is of a cross-sectional nature, was conducted on a small sample, did not evaluate first-tier ToM functions, and there were differences between the groups in terms of period of study and the level of income.

\section{REFERENCES}

1. Petersen RC. Mild cognitive impairment as a diagnostic entity. J Intern Med 2004;256(3):183-94. (PMID:15324362).

2. Tager-Flusberg H, Sullivan K. A componential view of theory of mind: evidence from syndrome. Cognition 2000;76(1):59-90. (PMID:10822043).

3. McCade D, Savage G, Guastella A, Lewis SJG, Naismith SL. Emotion recognition deficits exist in mild cognitive impairment, but only in the amnestic subtype. Psychol Aging 2013;28(3):840-52. (PMID:24041005).

4. Hughes CP, Berg L, Danziger WL, Coben LA, Martin $\mathrm{RL}$. A new clinical scale for the staging of dementia. Br J Psychiatry 1982;140:566-72. (PMID:7104545).

5. Folstein MF, Folstein SE, Mc Hugh PR. "Mini-mental state." A practical method for grading the cognitive state of patients for the clinician. J Psychiatr Res 1975;12(3):189-98. (PMID:1202204).

6. Güngen C, Ertan T, Eker E, Yaşar R, Engin F. Reliability and validity of the standardized mini mental state examination in the diagnosis of mild dementia in Turkish population. Turkish Journal of Psychiatry 2002;13(4):273-81. (PMID:12794644).

7. Baron-Cohen S, Wheelwright S, Hill J, Raste $Y$, Plumb I. The "Reading the mind in the eyes" test revised version: a study with normal adults, and adults with Asperger Syndrome or high-functioning autism. J Child Psychol Psychiatry 2001;42(2):241-51. (PMID:11280420).
The fact that the Hinting Test used in this study is easier to administer than other tests measuring the second-tier ToM functions and the narrow scoring range may have affected the results. On the other hand, this test may be insufficient in terms of measuring ToM functions compared to complex tests. The inadequacy of SMMSE in the differential diagnosis of $\mathrm{MCl}$ is another limitation of our study.

Finally, this study indicates that cognitive and affective ToM functions deteriorate independently of language and memory functions in aMCl patients. There is a need for further detailed studies to determine whether cognitive and affective ToM functions play a role in the evaluation of the risk of $\mathrm{aMCl}$ transformation into $\mathrm{AD}$.

8. Yıldırım EA, Kaşar M, Güdük M, Ateş E, Küçükparlak I, Özalmete EO. Investigation of the reliability of the "Reading the Mind in the Eyes Test" in a Turkish population. Turkish Journal of Psychiatry 2011;22(3):177-86. (PMID:21870307).

9. Corcoran R, Mercer G, Frith CD. Schizophrenia, symptomatology and social inference: investigating "theory of mind" in people with schizophrenia. Schizophr Res 1995;17(1):5-13. (PMID:8541250).

10. Eşsizoğlu A, Köşger F, Akarsu FÖ, Özaydın Ö, Güleç $\mathrm{G}$. Theory of mind and selective attention, response inhibition, cognitive flexibility in patients with schizophrenia. Arch Neuropsychiatry 2017;54(2):1627. (PMID:28680315).

11. Kaplan E, Goodglass H, Weintraub S. The Boston Naming Test. Lea \& Febiger, Philadelphia 1983, pp 1-60.

12. Wechsler D. WAIS-R Manual: Wechsler Adult Intelligence Scale-Revised. The Pschological Corporation, New York 1981, pp 1-156.

13. Sezgin N, Baştuğ G, Yargııı Karaağaç S, Yılmaz B. Turkish standardization of Wechsler Adult Intelligence Scale-Revised (WAIS-R): pilot study. Ankara University Journal of Languages and HistoryGeography 2014;54(1):451-80. (in Turkish).

14. Tanör ÖÖ. Handbook of Öktem Verbal Memory Process Test (Öktem-VMPT). Publication of Turkish Psychological Association, Ankara 2011, pp 1-97. (in Turkish). 
15. Goodglass H, Kaplan E. The assessment of aphasia and related disorders. Philadelphia, Lea and Febiger 1983, pp vii-70.

16. Cangöz B, Karakoç E, Selekler K. The norm determination and validity-reliability studies of clock drawing test on Turkish adults and elderlys (ages 50 and over). Turkish Journal of Geriatrics 2006;9(3):13642.

17. Yesavage JA, Brink $T L$, Rose $T L$, Lum $O$, Huang $V$, Adey M, Leirer VO. Development and validation of a geriatric depression screening scale: a preliminary report. J Psychiatric Research 1983;17(1):37-49. (PMID:7183759).

18. Ertan T, Eker E. Reliability, validity and factor structure of the Geriatric Depression Scale in Turkish elderly: are there different factor structures for different cultures. Int Psychogeriatr 2000;12(2):16372. (PMID:10937537).

19. Pfeffer RI, Kurosaki TT, Harrah $\mathrm{CH}$, et al. Measurement of functional activities in older adults in the community. J Gerontol 1982;37:323-9.

20. Selekler K, Cangöz B, Karakoç E. Adaptation and norm determination study of the Functional Activities Questionnaire (FAQ) on Turkish adults (ages 50 and over). Turkish Journal of Neurology 2004;10(2):102-7.
21. Cho $H$, Jeon $S$, Kim $C$, et al. Higher education affects accelerated cortical thinning in Alzheimer's disease: a 5-year preliminary longitudinal study. Int Psychogeriatr 2015;27(1):111-20. (PMID:25226082).

22. Evans DA, Hebert LE, Beckett LA, et al. Education and other measures of socioeconomic status and risk of incident Alzheimer disease in a defined population of older persons. Arch Neurol 1997;54(11):1399-405. (PMID:9362989).

23. Balthazar FLM, Cendes F, Damasceno BP. Semantic error patterns on the Boston Naming Test in normal aging, amnestic mild cognitive impairment and mild Alzheimer's disease: is there semantic disruption. Neuropsychology 2008;22(6):703-9. (PMID:18999343).

24. Baglio F, Castelli I, Alberoni M, et al. Theory of mind in amnestic mild cognitive impairment: an fMRI study. J Alzheimers Dis 2012;29(2):25-37. (PMID:22156049). 